\title{
In-Service EFLTeachers Engagement in Reflective Practice: What tools do in-service Teachers Utilize to Reflect their Teaching?
}

\author{
Anjar Nur Cholifah' ${ }^{1}$, Abdul Asib², Suparno ${ }^{3}$ \\ Universitas Sebelas Maret, Indonesia ${ }^{1,2,3}$ \\ Email: anjarcholifah@gmail.com ${ }^{1}$ \\ Email: abdulasib@yahoo.com ${ }^{2}$ \\ Email: drs.suparno@rocketmail.com ${ }^{3}$
}

\begin{abstract}
As long-life learners, teachers should not stop learning and evaluating their teachinglearning process. One of the ways to evaluate or reflect teacher's teaching is by conducting reflective practice. Reflective practice or sometimes called reflective teaching is not a new concept. In education field, reflective teaching has been enforced as a means to develop teacher professionalism. This study aims at reviewing some reflective practice tools utilized by in-service teachers in reflecting their classroom performance as an attempt to improve their teaching. Two in-service teachers with teaching experience ranging from 3-10 years are concerned with this research. Data gained through interview. The data collected are compiled by applying Miles, Huberman, \& Saldana's (2014) interactive model data analysis. The results of data analysis reveal the individual differences among in-service teachers' preference in doing reflection toward their teaching. The finding of this study leads in-service teachers to know kinds of tools used in reflective practice in their teaching-learning process to improve their teaching quality and learning outcomes.
\end{abstract}

Keywords: Reflective Practice, Reflective Teaching Tools, Teacher Professional Development

\section{INTRODUCTION}

Generally, people perceive that teacher has an important part in education to transfer knowledge to the students in teaching-learning processs. Then, every teacher should reflect and evaluate their teaching activity to imporve their teaching practice (Fatemipour, 2013). In teaching activity, reflective is considered as reflective practice.. Thus, it can be concluded that being a teacher is not an easy matter. Teachers should improve their capability and knowledge regarding their teaching-learning style or method. To conceive valuable teaching, teachers should acquire sense of thinking in order to make better teaching (Brookfield cited in Miller, 2010). Choy and Oo (2012) also described that by using reflective teaching would enhance the teacher's critical thinking. Furthermore, reflective practice demands the teachers to have sense of thinking about how to create a good teaching situation and 
stimulate the teachers to reflect themselves regarding their teaching-learning activity. (Zalipour, 2015).

Reflective practice as one of tools to develop teachers' professionalism has long been applied in education range. Reflective practice is expected to improve teacher performance in the classroom which later on will affect students' learning and learning outcomes. As lifelong learners, teachers should continue learning and evaluate their teaching to create meaningful learning for their students. Today, people have to be ready to do an evaluation, which its information changes regularly (Dyke, 2006) to meet with their social culture. Therefore, reflection is a key aspect to make teachers become more concern to the concept of reflective practice (Farrell, 2015). Related to this situation, reflective teachers need to pay more attention to reflective practice activity. Reflective practice is recognized as an adequate tool to promote teacher's professional development because it provokes teachers to reflect or investigate their teaching by looking at several aspects, such as teaching and learning materials, classroom activities, classroom management, etc. In other words, reflective practice is beneficial for teachers as Farrell (2012) argues that reflective practice helps teachers make critical reflection on all aspects of their work, so they can make an informed decision for the betterment of their work performance. While, Richards \& Farrell (2005) say teachers need to engage with current issue in education field such as the newest curriculum, research on second language acquisition, and the way to make an assessment. Farrell (1999) claimed that reflective teaching encourages teachers to appraise teachers' excellent understanding of their teaching practice and how their teaching would be effective.

In Indonesia context, reflective teaching practice or reflection is a latest issue in the educational field since the government propose the term of reflective teaching in 2007 as the standards or competencies for teachers that focused on academic skill, good self-character, care about social environment and involve in advance practice (Ministry of National Education, 2007). This is supported by (Yanuarti \& Treagust, 2016) who find that little do Indonesian know that relfective teaching is one of the standards of competencies that is established by the government. Thus, Indonesian practitioners researchers should examine thoroughly reflective teaching to reinforce Indonesian teachers' professionalism.

English teachers can utilize reflective teaching in their teaching by using several existing tools, techniques, and strategies. Fatemipour (2009) stated in his research that several tools of reflective practicesuch as teacher's journal, peer observation, video/audio recording, and students' feedback could be applied in gaining the data. It can be concluded that the teacher could utilize several tools in doing reflection. Navabeedhan (2011) mentioned that peer observation and coaching are two of the most used tools by pre-service teachers while (Fatemipour, 2009) found that the teacher's diary/journal was the most effective tool/method than others.

Recently studies concerning EFL teachers in utilizing reflective practice investigated the using of a particular tool or strategy to explore novice teachers' reflection in some countries: Hong Kong, Ireland, and Turkey (e.g. Lee, 2007; Harford \& MacRuairc, 2008; \& Susoy, 2015). However, those researchers strictly focus on examining one tool or strategy such as teacher journal, peer-videoing, and video recording used by a teacher to find out the efficiency and benefits. Moreover, other studies reported the contribution of reflective practice towards teaching activity and teacher development such as improving teaching performance, having selfconfidence, and more experienced in decisionmaking (Genc, 2010; Jung, 2012; \& Abednia, Hovassapian, Teimournezhad, \& Ghanbari, 
2013). Moreover, other studies reported the contribution of reflective teaching coming from Indonesia is under the title "In-Service Teacher's Perceptions of Reflective Teacher Diary to Promote Professional Development". In this study, Azizah (2018) had one teacher to be a participant in her research. She only focused on investigating the teacher's perception toward the utilizing of teacher diary to develop teacher's professionalism. Therefore, this research is conducted under some considerations including, firstly, In Indonesia, the research regarding reflection is still narrow. Equally, most of the research are only focus on one type of reflective teaching so it does not explore in a detailed way how the teachers utilize reflective teaching with some types of reflection. The problem explored in this research is the engagement of EFL teachers in practicing reflective teaching. Explicitly, it focuses on some tools of reflective practice used by EFL teachers in doing reflection over their teaching. Regarding the aforementioned research problem, the purpose of this study is to know some tools used by EFL teachers in conducting reflective teaching.

\section{The Definition of Reflective Practice}

Dewey (1933) illustrated reflective practice by describing that the "effective, constant, and accuarte consideration of any belief or supposed form of knowledge in the light of the grounds that reinforce it, and the more termination to which aims, creates reflective thought". Thus, by practicing reflective teaching, teachers will meet to concrentate on assessing how their teaching understanding and skills influence student engagement to improve their teaching practice. For Dewey, the use of reflective thought was to revamp the situation of dimness, reluctance, problem, and disruption into an exact, rational, completed, and harmonious one (Dewey, 1993, as stated in Lyons, 2010). Hence, it can be concluded that reflective practice is a transformation from the bad condition to a good condition in the teaching-learning process.
Moreover, Schön (1983) took up the concept of reflective practice and develop it into more relevant in education field such as: reflection-onaction, the evaluation which happens after teaching-learning activity, and reflection-inaction, the evaluation happens when the teachers are running the teaching-learning activity (cited in Schon, 2016). Moreoever, Van Manen (1991) completed the concept of reflection which is reflection-for-action, that focuses on the future of action that potentiollay happen to find possible alternatives (in Van Mannen, 2016).

Farrell (2004) portrays reflective practice as "qualifiate teachers to scrutinize the learning values and beliefs". Further, he builds up some reasons why teachers need to engage in reflective practice, those are; finding help when teachers feel helpless about their teaching, taking control over teachers working lives, and being empowered decision-makers. Valli as cited in Farrell (2004), identifies that through reflective practice teachers can look back and make a judgment about their teaching, and thereby they can find the solution for teaching problems. The usage of reflective teaching has been known worldwide. Farrell (2012) argues that the application of reflective practice in teacher professional development is based on the belief that teachers could enhance their teaching by practicing reflective teaching persistently. In order to apply reflective practice, teachers can use several tools of reflection. They are: teacher's journal, peer observation/coaching, students' feedback, audio recording/video recording, or action research (Lee, 2007; Fatemipour, 2013; Soisangwarn \& Wongwanich, 2014, and Susoy, 2015).

Moreover, (Tice, 2004) mentioned many kinds of reflective practice, first is teacher's diary, the teacher's diary is the most appicable tools to reflect teachers' teaching activity. In the diary, teachers not only take note about all the activities happened in the classrom, but aslo, write the students' response and feelings. In his 
research, (Fatemipour, 2009) calimed that the teacher's diary was the most effective reflective tool than other types of reflection. Another kind of reflective practice is peer observation. The teachers can make a plan with another teacher to be their peers and come to the class to observe teachers' perforamnce and in the end they could discuss everything about teaching-learning process and make some alternatives way to creat a better teaching practice. The third type of reflective practice is students' feedback. The teachers can ask the students to write comment on what they like or not among the learning process. Furthermore, although many things have been gained from the teacher's diary, students' feedback, or peer observation, they cannot remember/capture all moments that happened during the class. For many reasons, audio or video recording could be an alternative tools in practicing reflective teaching. It can capture many things that happened in the claas. Furthermore, it could recall the memory of teaching-learning process. In (MacKinnon's as cited in Jaeger, 2013), teachers and peers watched the recorded video of the lessons. Then, they worked together to establishe the problem happened in the class, discuss the problem, and the last they discuss together the potential solution toward the problems that happened. Those are the methods in conducting reflective practice. Teachers could use one or all of them. It depends on teachers' necessity. The most important thing is that those tools will support the teachers to do some evaluations on their teaching practice/performance.

\section{METHOD}

Depict to the goal of the study, this study applied descriptive qualitative design which focuses on the teachers' engagement in practicing reflective teaching by using several existing tools of reflection. B. Hancock (2002) states that qualitative research is involved with explaining social phenomena and to answer the how and why questions. In addition, multiple sources of proof or triangulation as described by (M.B. Miles \& A.M. Huberman, 1994); (R.K. Yin, 2003); and (R.S. Malik \& F.A. Hamied, 2014) become another aspect of this study approach. The usage of triangulation was also meant to cultivate the validity of the whole study (Miles \& Huberman, 1994; Yin, 2003; and Malik \& Hamied, 2014).

The participant in this study were two English teachers, the female one is from one of the senior high schools in Surakarta, Central Java, Indonesia with 10 years of teacher's experience while another one is a male teacher from one of the senior high schools in Kartasura with 2 years teaching experience. The teachers are selected to be the participant due to their experience in teaching English and they often to do some evaluation by utilizing reflective teaching. Besides, the participants showed a great interest in reflective teaching, though they stated that they still face several obstacles in applying reflective teaching. Therefore, the researcher used a purposive sampling method as described by (J.W. Creswell, 2009) to choose the partciipant.

The data were obtained by using one technique, namely: in-depth interview. The indepth interview was conducted with the teacher to collect the main data about their types of reflection that they used in the classroom regarding the practicing of reflective teaching. The interview session was conducted on Sept 20 2019. During the interview sessions, note-taking was done to gather important data (Miles \& Huberman, 1994; and Malik \& Hamied, 2014).

In collecting data, the procedural was applied model by (M.B. Miles \& A.M. Huberman, 1994), as cited also in (R.S. Malik \& F.A. Hamied, 2014), consist of data reduction, data display, and conclusion drawing/verification. 


\section{FINDINGS AND DISCUSSION}

The following table shows some tools utilized by EFL teachers in doing reflection on their teaching. There are 4 tools employed by the participants in reflective practice, those are teacher's diary/journal, peer observation, students' feedback, and audio/video recording. There is no peer coaching session conducted by the participants because to do this activity, they need support and funding from the school. To make it clear, the percentage is presented in the table below:

Table 1. Summary of Reflective Practice Tools Utilized by In-service Teachers

\begin{tabular}{clc}
\hline No. & Tools Utilized & Percentage \\
\hline 1. & Teacher's Journal & $50 \%$ \\
2. & Peer Observation & $100 \%$ \\
3. & Students' Feedback & $100 \%$ \\
4. & Audio/Video Recording & $50 \%$ \\
\hline
\end{tabular}

From the table, peer observation and students' feedback are the most common tools utilized by the respondents. Before they claimed that they used some tools in doing reflection, they have already known how the way in doing reflection in the classroom. As stated by teacher 2 in our interview:

Teacher: "Reflective practice yang saya tahu itu merupakan sebuah metode untuk seorang guru dalam merefleksi dirinya dalam mengajar. Apakah pengajaran hari ini sudah bagus atau belum, apa saja yang terjadi dikelas, bagaimana tanggapan siswa, sehingga guru bisa merefleksi, membuat evaluasi dan merencanakan metode pengajaran yang tepat untuk pertemuan selanjutnya. Namun, sampai saat ini saya masih suka bingung untuk penerapan reflective teaching karena kurangnya pengetahuan saya tentang itu. Saat kuliah saya tidak belajar mendalam."
Translation: "Reflective practice that I know is a method for teachers in doing a reflection in teaching. Is the method good for the students? What happens in the classroom? How do the students' reaction? So that the teachers could do a reflection, an evaluation and plan an appropriate method for the next meeting. However, I still get confused while doing a reflection because of the limitation of my knowledge regarding reflective teaching. When I was in collage, I did not study the subject deeply."

The response from the teacher 2 is in line with Mathew, et al. (2017) who stated that reflective practice is a tool to do an evaluation the teachers' teaching performance in order to enhance their teaching practice. It proves as thorough approach that facilitates the teacher to reflect on their teaching-learning acticit. Additionally, Boody (2008) said that teacher's reflection classified as assessment/evaluation, problem-settlement, critical analysis, and practicing what is in mind into an action. Further, reflective practice requisites the teachers to enhance the teaching values and beliefs, consequently the teachers can be responsible toward it (Korthagen, 1993, as cited in Farrel, 2003). Even the teacher still got difficulties in doing a reflection because of the lack of understanding, he still believed that reflective practice is a good way to do a reflection for all teachers.

In addition, teacher 1 mentioned that reflective practice is worth to be applied because it helps her in the improvement of her teaching practices. Because of doing a reflection, the teacher said that she could be a creative teacher after know the students' response, as following here:

Teacher: "Sudah jelas ya, bahwa reflective teaching itu bagus, guru dapat tahu kekuatan dan kelemahan dirinya 
dalam mengajar dan kita juga jadi tahu pencapaian siswa. Selain itu, dengan reflective teaching kita juga bisa tahu cara untuk improve our English skill, our teaching, our speaking style yang kemudian kita bisa tahu metode atau teknik yang cocok yang bisa kita pakai untuk setiap topik di pengajaran bahasa Inggris dan itu sesuai dengan kemampuan siswa. Dengan reflective teaching, itu memudahkan saya untuk menentukan cara mengajar yang tepat dipertemuan selanjutnya sehingga siswa tidak akan bosan karena kita telah mengganti metode yang tepat.

Translation: "It is absolutely distinct that reflective teaching is really worth to be applied. The teacher could identify the plus and minus of our teaching methods and also we could know more about our students' triumph. Besides, by doing a reflection, the teacher could know the way in improving our English skill, our teaching, and our spoken pattern in order to know preferrable method in teaching process based on the students' ability so that the students will feel fun because we have found another method to teach"

The response from the teacher 1 is in line with Rodman (2010) who mentioned that using refective teaching could be an appropriate approach to increase the teachers' improvement in teaching. Moreover, the teacher said that by applying reflective teaching, she could know her plus and minus of her performance and the teacher could identify the efficiency of the technique/method used in their teaching. In addition, Calderhead, (1992 as cited in Al-Ahdal \& Al-Awaid, 2014) mentioned that reflective practoces enhanced teachers' creativity to build an ingenious mehod in teaching and it also built learning chances for the students. It can be concluded that reflection could be stem for the future teaching's strategy.

With the respect to the awareness of the reflective practice, it can be assumed that the teachers have a good perception because by doing a reflection could give some benefits not only for the teacher but also for the students.

Second, Types of Reflection that Utilized by the Teachers. From the obtained data, it was found that the teachers used some types of reflective practice such as teacher's diary, students' feedback, peer observation, and video recording. Teacher 1 mentioned that she often uses some types of reflective teaching depend on her needs in doing a reflection. The gained data about the statement are as follow:

Teacher: "Kalau untuk tipe dari reflection, yang sering sekali saya pakai adalah teacher's journal, saya bisa mencatat segala fenomena yang terjadi dikelas. Ataupun nama-nama siswa yang sekiranya tidak terlihat tertarik dengan pelajaran. Saya juga suka mencatat metode serta games yang bisa saya pakai saat mengajar, sehingga dilain waktu saya bisa melihat catatan lagi untuk mengaplikasikan cara yang sama. Selain itu, pihak sekolah juga setiap dua pekan sekali melakukan peer-observation untuk guru-guru, saya senang dengan adanya itu karena saya bisa menanyakan langsung kepada yang mengobservasi untuk memberi penilaian terhadap teaching style saya. Selain itu saya juga sering memberikan kuisioner kepada siswa untuk tahu apakah mereka nyaman dengan metode pembelajaran saya, bagaimana perasaan mereka, metode apa yang mereka butuhkan, jadi ada timbal balik antara guru dengan murid. Terkadang juga saya menaruh HP di ujung ruangan untuk bisa merekam saya dalam keseluruhan mengajar, jadi saya 
bisa tahu body language saya terhadap anak-anak. Semua itu sangat membantu saya dalam melakukan reflective teaching. Jadi tidak hanya fokus kepada satu tipe saja, tetapi saya juga menggunakan yang lain."

Translation: "For types of reflective teaching, I often use teacher's journal, I could write all the phenomenon that happens in the classroom. Besides, I could write all the students' names who do not interest in the lesson. I also take note for method or games that I used in the teaching-learning process so for the next teaching I could use the same method. Besides, twice a week our school will hold peer observation for all teachers. I am very glad about peerobservation because I could ask the observer about my teaching style. Moreover, I often give my students a questionnaire to know if they feel comfortable in the process of teachinglearning. I could know their feeling, and the suitable method for them in order to get feedback between teachers and students. All the types of reflective teaching are really help me in doing a reflection. Not only focus on one type, but also other types.

It is in line with Mathew, et al. (2017) who mentioned that tools of reflection such as peer observation, students' feedback, video recording also teacher's diary could be utilized as the methods to hold reflection. Those types could be an effective idea of gaining the data related to the reflection of the teaching-learning process. In this research, the most used type of reflection was the teacher's diary $t$ followed by peer observation, students' feedback, and video recording. Zulkifar and Mujiburrahman (2017) who did a research about reflective journals mentioned that most of the participants perceived that reflective journals could be an effecient tool to enhance the teachers' performance. Another research, Fatemipour (2009) also supported that the teacher's journal/diary is considered as the most effective reflective tool.

The finding from teacher 2 which is the male teacher, he said that the most frequent tools that he used to do a reflection was peer observation followed by students' feedback. The obtained data about the statement are as follow:

Teacher: "Saya rasa setiap guru pasti melakukan peer obersavtion ya, karena di masing-masing sekolah pasti ada observasi dan ada form observasi untuk guru. Jadi ada obersever yang ikut kedalam kelas kemudian menilai guru yang sedang mengajar, tidak hanya menilai namun juga memberikan feedback. Saya antusias sekali dengan peer obervation karena membuat saya terpacu untuk mempersiapkan bahan ajar dengan baik, dan saya juga semangat sekali untuk mengajar dikelas. Saya rasa ini hal baik ya, karena guru bisa berdiskusi dengan guru lainnya. Selain itu saya juga suka menyakan kepada siswa terkait cara saya mengajar, biasanya saya tanya langsung saja, tapi terkadang juga saya meminta mereka untuk menulis dikertas. Kita sebagai guru mengajar para murid jadi kita juga perlu tau maunya mereka seperti apa”.

Translation: "I think every teacher does peer observation/ peer teaching, it could happened because there is an observation and an observation form in each school for the teachers. There is an observer who joined the class to observe and assess the teacher. She/he is not only asses the teachers but also give feedback for their teaching practice. I am really excited about this tool because it can push me to prepare well the teaching materials and I 
am very excited to teach in the class. In my opinion, it is very good because the teachers could discuss with other teachers. Besides, I also used students' feedback to know their response to my teaching. I usually ask them to speak or to write on a piece of paper. We are as the teacher who teach students is needed to know their wants."

Soisangwarn \& Wongwanich (2013) stated that the benefits of peer observation can support teachers to know and understand themselves better and their students in order to make a meaningful learning activity. The teachers are more aware about their students' condition and promote the practice more effectively. It can be concluded that teachers could use some tools of reflection and create a better plnning and action.

\section{CONCLUSIONS}

As the fulfllment of this study reports the topic "In-Service EFL Teachers Engagement In Reflective Practice" the problem statement of the research was briefly reported. The participants of this research have a positive perception regarding reflective practice. It is worth to be applied and supports the teacher enhancing teachers' teaching skill. Furthermore, there areseveral tools/types of reflection that utilized by the teachers. The most used type of reflection were peer observation and students' feedback followed by teacher's journal and video recording. Furthermore, teachers encountered several benefits in using some tools in practicing reflective practice such as: could identify the students' demand and could discuss with other teachers, thus they could make a better teaching plan. As the finding that is previously stated above, the suggestion goes to the future researcher. Since this study is only have two participants, it would be respected if the future researchers could get some teachers to know their tools of reflective teaching that they used in doing a reflection and its benefits.

\section{REFERENCES}

Abednia, A., Hovassapian, A., Teimournezhad, S., \& Ghanbari, N. (2013). Reflective journal writing: Exploring in-service EFL teachers' perceptions. System, 503-514.

Al-Ahdal, A.A \& Al-Awaid, S. A. (2014). Reflective teaching and language teacher education programmes: A milestone in Yeemen and Saudi Arabia. Journal of Language Teaching and Research , 759768.

Azizah, U. A. (2018). In-service teachers' perceptions of reflective teacher diary to promote professional development. International Journal of Multicultural and Multireligious Understanding , 1-8.

Boody, R. M. (2008). Teacher reflection as teacher change, and teacher change as moral response. Education , 498-506.

Choy, S. C., \& Oo, P. S. (2012). Reflective Thinking and Teaching Practices: A Precursor for Incorporating Critical Thinking into the Classroom. International Journal of Instruction , 167-182.

Cresswell, J. (2009). Research design: Qualitative, quantitave, and mixed methods approaches. London: SAGE Publications, 3rd Edition.

Dewey, J. (1993). How we think: A restatement of the relation of reflective thinking to the educative process. Boston: D. C. Health.

Dyke, M. (2006). The role of the 'Other' in reflection, knowledge formation and action in a late modernity. International Journal of Lifelong Education, 105-123. 
Farrell, T. S. (2012). Reflecting on Reflective Practice: (Re) Visiting Dewey and Schon. TESOL Journal , 7-16.

Farrell, T. S. (2015). Reflective Language Teaching: From Research to Practice. London, UK: Continuum.

Farrell, T. S. (1999). Understanding Reflective Teaching. Teaching and Learning, 5263.

Fatemipour, H. (2009). The Effectiveness of Effective Teaching Tools in Englsh Language Teaching. The Journal of Modern Thoughts in Education .

Fatemipour, H. (2013). The Efficiency of the Tools Used for Reflective Teaching in ESL Contexts. Procedia-Social and Behavioral Sciences , 1398-1403.

Genc, Z. S. (2010). Teacher autonomy through reflevtive journals among teachers of English as a foreign language in Turkey. Teacher Development , 397-409.

Hancock, B. (2002). An introduction to qualitative research. Nottingham, UK: Trent Focus Group.

Harford, J., \& MacRuairc, G. (2008). Engaging student teachers in meaningful reflective practice. Teaching and Teacher Education , 1884-1892.

Jaegar, E. (2013). Teachers' reflection: supports, barriers, and supports. Issues in Teacher Education .

Jung, J. (2012). The focus, role, and meaning of experienced teachers' reflection in physical education. Physical Education and Sport Pedagogy, 157-175.

Lee, H. J. (2005). Understanding and assessing preservice teachers' reflective thinking.
Teaching and teaccher education , 699715 .

Malik, R. \&. (2014). Researcher methods: A guide for first time reseacher. Bandung: UPI Press.

Mathew, P., Mathew, P., \& Peechattu, P.J. (2017). Reflective practices: A means to teacher development. Asia Pacific Journal of Contemporary Education and Communication Technology (APJECT), 126-131.

Mile, M.M. \& Huberman, A.M. (1994). Qualitative data analysis: An expanded source book. USA: SAGE Publication, Inc., 2nd Edition.

Miller, B. (2010, March). Brookfield's Four Lense: Becoming a Critically Reflective Teacher. Dipetik August 12nd, 2019, dari https://valenciacollege.edu/faculty/devel opment/coursesresources/documents/brookfield_summa ry.pdf

National, M. of E. (2007). Standar Kualifikasi Akademik dan Kompetensi Guru. Diambil kembali dari https://doi.org/10.1017/CB09781107415 324.004

Richards, J. C., \& Farrell, T. S. C. (2005). Professional Development for Language Teachers: Strategies for Teacher Learning. New York, NY: Cambridge University Press.

Rodman, G. J. (2010). Facilitating the teachinglearning process through the reflective engagement of pre-service teachers. Australian Journal of Teacher Education , 20-34. 
Schon, D. A. (2016). The reflective practitioner: How professionals think in action. New York, NY: Routledge.

Schon, D. (1983). The reflective practitioner: How professionals think in action. London: Temple Smith.

Soisangwarn, A., \& Wongwanich, S. (2015). Promoting the reflective teacher through peer coaching to improve teaching skills. ProcediSocial and Behavioral Sciences, 163-171.

Susoy, Z. (2015). Watch your teaching: A reflection strategy for EFL pre-service teachers through video recordings. Procedia- Social and Behavioral Sciences , 163-171.

Tice, J. (t.thn.). Reflective teaching: Exploring our own classroom practice. Dipetik April 4th, 2019, dari https://www.teachingenglish.org.uk/artic le/reflective- teaching-exploring-ourown-classroom-practice

Van Mannen, M. (2016). The meaning of pedagogical thoughtfulness. New York, NY: Routledge.

Yanuarti, E., \& Treagus, D. F. (2016). Reflective Teaching Practice: Teacher' Perspectives in an Indonesia Context. Continuing Professional Development , 280-284.

Zalipour, A. (t.thn.). Reflective Practice. Dipetik August 10th, 2019, dari Teaching Development Unit: The University of Waikato: www.waikato.ac.nz

Zulkifar, T. \& Mujiburrahman. (2017). Understanding own teaching: Becoming reflective teachers through reflective journals. Diambil kembali dari Reflective Practice: doi: $10.1080 / 14623943.2017 .12959337$ 